\title{
Knowledge of nurses in primary health care about the indication of special coverage
}

\section{Conhecimento do enfermeiro da atenção primária à saúde sobre a indicação de coberturas especiais}

\section{Conocimiento del enfermero de la atención primaria a la salud sobre la indicación de coberturas especiales}

\author{
Cristiano Caveião ${ }^{1,2}$, Ana Paula Hey³, Willian Barbosa Sales², Edson Luís Pereira Tavares², \\ Elisangela de Souza², Marly Marton Bittencourt Gervásio da Silva ${ }^{4}$
}

ORCID IDs

Caveião C (1D https://orcid.org/0000-0003-2664-7542

Sales WB (D) https://orcid.org/0000-0003-2367-8271

Tavares ELP (D) https://orcid.org/0000-0002-5833-8763

Souza E (ID https://orcid.org/ 0000-0001-7194-9764

Silva MMBG (D) https://orcid.org//0000-0002-0940-8382

\section{HOW TO CITE}

Caveião C, Hey AP, Sales WB, Tavares ELP, de Souza E, da Silva MMBG. Conhecimento do enfermeiro da atenção primária à saúde sobre a indicação de coberturas especiais. ESTIMA, Braz. J. Enterostomal Ther., 16: e3118. https://doi.org/10.30886/estima.v16.562.

\begin{abstract}
Objective: To identify the knowledge of nurses in primary health care in a municipality about the indication of special coverage. Method: An exploratory, descriptive study with a quantitative approach performed with 101 nurses in 109 health units of primary health care through a structured instrument. The data were statistically analyzed with frequency distribution, percentiles, average, median, standard deviation, coefficient of variation, confidence interval, p-value and two-proportion equality test to compare the group that has qualification/improvement in the area with the group do not have. Results: About the indication of the coverage, 79.2\% reported that it is intended to control exudate and non-viable tissue, and the indication with the highest percentage of correct answers for use in wounds was the silver hydrofibra coverage and hydrocolloid with silver. Conclusion: Primary care nurses with qualification/improvement courses do not have enough knowledge to indicate the coverage.
\end{abstract}

DESCRIPTORS: Nursing; Occlusive healings; Knowledge; Primary health care; Stomatherapy.

\footnotetext{
${ }^{1}$ Centro Universitário Internacional - Escola Superior de Saúde, Biociências, Meio Ambiente e Humanidades - Curitiba/PR - Brazil. ${ }^{2}$ Centro Universitário Autônomo do Brasil - Escola de Ciências da Saúde - Curso de Enfermagem - Curitiba/PR - Brazil.

${ }^{3}$ Universidade Tuiuti do Paraná - Faculdade de Ciências Biológicas e da Saúde - Curso de Enfermagem - Curitiba/PR - Brazil.

${ }^{4}$ Universidade Positivo - Escola de Ciências da Saúde - Curso de Enfermagem - Curitiba/PR - Brazil.

Corresponding author: Cristiano Caveião | Rua Treze de Maio, 538 - Centro | ZIP Code: 80510-030 - Curitiba/PR

E-mail: cristiano_caveiao@hotmail.com

Received: Dec. 11, 2017 | Accepted: Nov. 21, 2018
} 


\section{RESUMO}

Objetivo: Identificar o conhecimento dos enfermeiros da atenção primária à saúde de um município sobre indicação de coberturas especiais. Método: Estudo exploratório, descritivo, com abordagem quantitativa realizado com 101 enfermeiros em 109 unidades de saúde da atenção primária em saúde por meio de instrumento estruturado. Os dados foram analisados estatisticamente com a distribuição de frequência, percentis, média, mediana, desvio padrão, coeficiente de variação, intervalo de confiança, p-valor e teste de igualdade de duas proporções para comparar o grupo que tem capacitação/aperfeiçoamento na área com o grupo que não tem. Resultados: Sobre a indicação da cobertura, 79,2\% referiu que se destina a controlar o exsudato e o tecido não viável, e a indicação com maior porcentagem de acertos para utilização em feridas foi a cobertura hidrofibra de prata e hidrocoloide com prata. Conclusão: Enfermeiros da atenção primária com cursos de capacitação/aperfeiçoamento não têm conhecimento suficiente para indicação das coberturas.

DESCRITORES: Enfermagem; Curativos oclusivos; Conhecimento; Atenção primária à saúde; Estomaterapia.

\section{RESUMEN}

Objetivo: Identificar el conocimiento de los enfermeros de la atención primaria a la salud de un municipio sobre la indicación de coberturas especiales. Método: Estudio exploratorio, descriptivo, con abordaje cuantitativo realizado con 101 enfermeros en 109 unidades de salud de la atención primaria en salud por medio de instrumento estructurado. Los datos fueron analizados estadísticamente con la distribución de frecuencia, percentiles, promedio, mediana, desvío estándar, coeficiente de variación, intervalo de confianza, p-valor y prueba de igualdad de dos proporciones para comparar el grupo que tiene capacitación/perfeccionamiento en el área con el grupo que no lo tiene. Resultados: Sobre la indicación de la cobertura, 79,2 \% indicó que está destinado a controlar el exudado y el tejido no viable, y la indicación con mayor porcentaje de aciertos para utilización en heridas fue la cobertura hidrofibra de plata e hidrocoloide con plata. Conclusión: Enfermeros de la atención primaria con cursos de capacitación/perfeccionamiento no tienen conocimiento suficiente para la indicación de las coberturas.

DESCRIPTORES: Enfermería; Curativos oclusivos; Conocimiento; Atención primaria a la salud; Estomaterapia..

\section{INTRODUCTION}

Primary health care (PHC) is a set of organizational strategies for care in a regionalized, continuous and systematized way in which preventive, curative, accountability, humanization, equity, individual, social and community participation are integrated ${ }^{1}$. According to the Ministry of Health, $\mathrm{PHC}$ is a specialized service and a preferred gateway to the Unified Health System (UHS), which occurs in a comprehensive and universal way, involving health promotion, protection and recovery actions $^{2}$. In the service network of the Municipal Health Department (MHD) of the municipality surveyed, aiming at the best assistance in PHC, the service started to offer, in 2015, treatment of acute and chronic wounds of different etiologies.

In PHC, it is part of the daily routine of the nurse the treatment of wounds ${ }^{3}$. With the evaluation of the patient in a systematized way, it contemplates the anamnesis, the physical examination, the nursing diagnosis, the interventions, the nursing prescriptions and the referrals. During the consultation, the care plan is developed to choose the ideal coverage and follow the evolution of the wound, in order to observe the effectiveness of the treatment. These measures can reduce wound complications such as infections and amputations ${ }^{4}$.

Knowledge and skills of nurses in wound care in PHC are regulated by Resolution no 567 of January 29, 2018, which defines the responsabilities of nurses in wound care: performing healings, supervising the nursing staff in care wounds, clinic opening for wound care, prescribing medications and wounds cover, and performing chemical and mechanical debridement on wounds ${ }^{5}$.

The wound is considered to be loss of tegument continuity, represented not only by the rupture of the skin and the subcutaneous cellular tissue, but also, in some cases, muscles, tendons and bones. It can be classified as etiology, complexity and time of existence ${ }^{6}$. The most common predisposing factors of wounds are prolonged hospitalization, age, obesity, nutritional status and diabetes mellitus ${ }^{7}$. Its treatment depends on the evolution of the tissue repair process, including clinical and surgical 
methods, with curative and special coverage being the most frequently used clinical method ${ }^{8}$. To be successful, it requires evaluation by the nurse so that it can indicate which special coverage is appropriate for each objective.

The curative is the therapeutic means that consists in the cleaning, with application of aseptic procedures, that goes from the irrigation with physiological solution until the special coverings that will be able to assist in each moment of the scar process. These coverages were developed with different objectives for each situation, but clearly defined as to their indication".

The choice of the special coverage and the most suitable material for the treatment includes the pathophysiological and biochemical knowledge of the mechanisms of tissue healing and repair, etiology, injury location, wound size, clinical conditions and stages of the cicatrization process. The coverages can be classified as passive, with the function of only covering the wounds (gauze, non-adhering gauze) and bioactive (releasing elements necessary for healing and accelerate the cicatrization $)^{4,5,9,10}$. However, the choice of ideal coverage deserves special attention from nurses, based on their knowledge of wound evaluation. It still needs to take into account the coverage available in the market, as well as its composition, mechanisms of action, indication, use and the interval between exchanges.

Therefore, in view of this contextualization, the indication of adequate coverage for each type of wound can contribute to the scar process, avoiding late complications, such as soft tissue sepsis and even amputation. In addition to improving the patient's condition, the prescription and correct application of the covers help in the fast and effective treatment. This study aimed to identify the knowledge of the nurses of the PHC about the indication of special coverages.

\section{METHODS}

This is an exploratory, descriptive study with a quantitative approach performed with nurses in 109 PHC health units of a municipality in the South Region of Brazil. 321 nurses working in PHC were invited to participate in the study, however 220 refused to participate or were absent during the study period. The sample consisted of 101 nurses.
Inclusion criteria were nurses who were filled in the PHC and who performed special coverage prescription, and the exclusion criteria were nurses absent during the period of data collection, vacation or leave (health treatment, maternity, guardianship council, selective mandate, treatment family health, without salaries, decennial award and quinquennium award).

After confirmation with the local health authority (LHA) of the health units to survey the number of nurses in each unit, invitations were sent to all and delivered the instrument of information collection and the Informed Consent Form. The interview was scheduled at a predefined date and time with LHA and occurred at the health facility itself, in a private location.

The information gathering was collected in September 2017 , through a structured instrument, prepared by the researchers themselves, containing closed multiple choice questions related to the indication of the special coverage provided by the MHD and used by the nurses. The relationship of the special coverages was obtained through the protocol of treatment of wounds, being the following coverage: essential fatty acids; calcium alginate and sodium; activated charcoal; hydrogel; polyurethane foam with silver; non-adhering gauze; hydrofibra with silver; and hydrocolloid plate. Variations in special coverage may occur because of updates to the protocol that have not yet been disclosed. After the instrument was built, it was evaluated by two nurses and stomatherapists.

After the data were collected, they were typed into a Microsoft Excel Office ${ }^{\circledR} 2010$ worksheet, using double typing to avoid margin of error. Statistical analysis of the data was performed using the Statistical Package for Social Science (SPSS) version 17.0 and the results were presented by frequency distribution, percentiles, average, median, standard deviation (SD), coefficient of variation, confidence interval, $\mathrm{p}$-value and equality test of two proportions to compare the group that has qualification/ improvement in the area with the group that does not have. The results were analyzed through literature on the subject. The calculated sample error was 5\%.

Ethical aspects were respected in all stages of the study, in accordance with Resolution no 466 of December 12,2012 , which addresses the recommendations that regulate research involving human beings ${ }^{11}$. The study was approved by the research ethics committee involving 
human beings (CAEE 69191517.3.0000.0101, opinion 2.230.211).

\section{RESULTS}

The study allowed to analyze the knowledge of the nurses of the PHC units of the city about the indication of special coverings for wound treatment. The data obtained allowed the characterization of the nurses regarding the sociodemographic aspects.

A total of 101 nurses participated in the study, 96\% (97) of women, with a mean age of 44.2 years $(\mathrm{SD} \pm 8.4$ ), a median of 43 years, a minimum of 22 and a maximum of 64 years. As to the year of completion of nursing graduation, most nurses completed their courses in the decades of $2000(56.4 \%, \mathrm{n}=57)$ and $1990(21.8 \%$, $\mathrm{n}=22)$. Regarding specialization, $84.2 \%(\mathrm{n}=85)$ have a specialization course lato sensu (Table 1 ), with $45.8 \%$ $(\mathrm{n}=38)$ in the family health/collective health area and 3\% $(\mathrm{n}=3)$ are masters. During the qualification, $65.3 \%(\mathrm{n}=66)$ reported having studied contents related to special coverage.

Table 1. Characterization of nurses regarding the decade of formation and specialization latu sensu, 2017.

\begin{tabular}{|c|c|c|}
\hline Variable & $\mathrm{n}(\%)$ & p-value* \\
\hline \multicolumn{3}{|l|}{ Course conclusion (decade) } \\
\hline 1970 & $2(2.0)$ & $<0.001$ \\
\hline 1980 & $9(8.9)$ & $<0.001$ \\
\hline 1990 & $22(21.8)$ & $<0.001$ \\
\hline 2000 & $57(56.4)$ & Reference \\
\hline 2010 & $11(10.9)$ & $<0.001$ \\
\hline \multicolumn{3}{|l|}{ Post-graduation } \\
\hline Administration & $2(2.4)$ & $<0.001$ \\
\hline Audit & $6(7.2)$ & $<0.001$ \\
\hline Emergency & $12(14.5)$ & $<0.001$ \\
\hline Nursing work & $6(7.2)$ & $<0.001$ \\
\hline Nursing in a surgical center & $1(1.2)$ & $<0.001$ \\
\hline Stomatheraphy & $2(2.4)$ & $<0.001$ \\
\hline Health management & $5(6.0)$ & $<0.001$ \\
\hline Public administration & $2(2.4)$ & $<0.001$ \\
\hline Hospital infection/epidemiology & $2(2.4)$ & $<0.001$ \\
\hline Obstetrics & $6(7.2)$ & $<0.001$ \\
\hline Pediatrics & $1(1.2)$ & $<0.001$ \\
\hline Family health/Collective health & $38(45.8)$ & $<0.001$ \\
\hline
\end{tabular}

*Equality test of two proportions.
Regarding the duration of PHA, the mean was 13.1 years $(\mathrm{SD} \pm 6.9)$, with a median of 11 , a minimum of 1 and a maximum of 32 years. When it asked about the amount of special coverage performed per month in the service, the mean was $8.1(\mathrm{SD} \pm 12.2)$, with a median of 4 . Referring to qualification courses in wound treatment, $77.2 \%(\mathrm{n}=78)$ performed and $93.1 \%(\mathrm{n}=94)$ did further qualification courses in 2017.

When it asked about ideal coverage, 79.2\% $(n=80)$ responded that they should control exudate and nonviable tissue and be biocompatible (Table 2).

Table 2. Characterization of nurses regarding indication of coverage, 2017.

\begin{tabular}{lcc}
\multicolumn{1}{c}{ The ideal coverage should } & $\mathbf{n}(\%)$ & p-value* \\
\hline $\begin{array}{l}\text { To control the exudate and non- } \\
\text { viable tissue }\end{array}$ & $80(79.2)$ & Reference \\
To keep the wound bed moist and & $70(69.3)$ & 0.108 \\
the surrounding skin dry & $57(56.4)$ & $<0.001$ \\
To have selective permeability for & $44(43.6)$ & $<0.001$ \\
oxygen ingress & $80(79.2)$ & Reference \\
\hline
\end{tabular}

*Equality test of two proportions.

With regard to the indication of each special coverage used in the PHC and included in the MHD Wound Treatment Protocol, it should be noted that the special coverage and the indication of each one were listed, and it is up to the nurses to choose the best indication for each coverage. A comparison was also made between the group of nurses who has qualification/improvement in wounds and the group that does not have and it is observed that there is no statistically significant difference between the groups for the distribution of the treatments, that is, the groups are homogeneous/(Table 3).

\section{DISCUSSION}

The feminine presence is a highlight in nursing since ancient practices, due to the art of caring for the most different forms, which was conceived through past knowledge from generation to generation. Under the influence of Florence Nightingale, the feminization of the profession occurred due to the idea of the vocation of women to care ${ }^{11}$. 
Table 3. Kknowledge of nurses for the indication of special coverage, 2017.

\begin{tabular}{|c|c|c|c|c|c|}
\hline \multirow{2}{*}{ Coverage } & \multicolumn{2}{|c|}{ General group } & \multirow{2}{*}{$\begin{array}{l}\text { Group with } \\
\text { qualification/ } \\
\text { improvement } \\
n(\%)\end{array}$} & \multirow{2}{*}{$\begin{array}{c}\text { Group without } \\
\text { qualification/ } \\
\text { improvement } \\
n(\%)\end{array}$} & \multirow{2}{*}{$p$-value* } \\
\hline & n (\%) & p-value* & & & \\
\hline \multicolumn{6}{|l|}{ Calcium Alginate } \\
\hline Autolytic & $43(42.6)$ & $<0.001$ & $34(24.8)$ & $9(25.7)$ & 0.913 \\
\hline Moisture control & $67(66.3)$ & Reference & $56(40.9)$ & $11(31.4)$ & 0.306 \\
\hline \multicolumn{6}{|l|}{ Silver Foam } \\
\hline Antimicrobial & $84(83.2)$ & Reference & $66(30.6)$ & $18(30.5)$ & 0.994 \\
\hline Autolytic & $33(32.7)$ & $<0.001$ & $27(12.5)$ & $6(10.2)$ & 0.625 \\
\hline Odour control & $58(57.4)$ & $<0.001$ & $43(19.9)$ & $15(25.4)$ & 0.357 \\
\hline \multicolumn{6}{|l|}{ Non-adhering gauze } \\
\hline Moisture maintenance & $70(69.3)$ & Reference & $59(49.2)$ & $11(45.8)$ & 0.766 \\
\hline \multicolumn{6}{|l|}{ Hydrocolloid } \\
\hline Autolytic & $42(41.6)$ & $<0.001$ & $36(21.4)$ & $6(15.4)$ & 0.398 \\
\hline Hydration & $42(41.6)$ & $<0.001$ & $34(20.2)$ & $8(20.5)$ & 0.969 \\
\hline Moisture maintenance & $70(69.3)$ & Reference & $58(34.5)$ & $12(30.8)$ & 0.655 \\
\hline \multicolumn{6}{|l|}{ Hydrocolloid with silver } \\
\hline Antimicrobial & $85(84.2)$ & Reference & $66(31.6)$ & $19(34.5)$ & 0.675 \\
\hline Autolytic & $34(33.7)$ & $<0.001$ & $28(13.4)$ & $6(10.9)$ & 0.624 \\
\hline Odour control & $43(42.6)$ & $<0.001$ & $33(15.8)$ & $10(18.2)$ & 0.669 \\
\hline Moisture control & $34(33.7)$ & $<0.001$ & $23(11.0)$ & $5(9.1)$ & 0.682 \\
\hline Hydration & $30(29.7)$ & $<0.001$ & $24(11.5)$ & $6(10.9)$ & 0.905 \\
\hline Moisture maintenance & $44(43.6)$ & $<0.001$ & $35(16.7)$ & $9(16.4)$ & 0.946 \\
\hline \multicolumn{6}{|l|}{ Silver Hydrofibre } \\
\hline Antimicrobial & $89(88.1)$ & Reference & $71(29.2)$ & $18(34.0)$ & 0.495 \\
\hline Autolytic & $39(38.6)$ & $<0.001$ & $32(13.2)$ & $7(13.2)$ & 0.994 \\
\hline Odour control & $53(52.5)$ & $<0.001$ & $43(17.7)$ & $10(18.9)$ & 0.840 \\
\hline Moisture control & $66(65.3)$ & $<0.001$ & $53(21.8)$ & $13(24.5)$ & 0.667 \\
\hline Moisture maintenance & $38(37.6)$ & $<0.001$ & $34(14.0)$ & $4(7.5)$ & 0.204 \\
\hline \multicolumn{6}{|l|}{$\begin{array}{l}\text { Hydrogel } \\
\text { Hol }\end{array}$} \\
\hline Autolytic & $81(80.2)$ & Reference & $65(39.6)$ & $16(32.7)$ & 0.377 \\
\hline Hydration & $58(57.4)$ & $<0.001$ & $43(26.2)$ & $15(30.6)$ & 0.544 \\
\hline Moisture maintenance & $57(56.4)$ & $<0.001$ & $42(25.6)$ & $15(30.6)$ & 0.488 \\
\hline
\end{tabular}

*Equality test of two proportions.

With regard to qualification, there was a greater predominance in the last decade, due to the great expansion of the offer of nursing graduation courses ${ }^{12}$, coming from government incentives such as scholarships.

After the implementation of the National Curricular Guidelines for Nursing ${ }^{13}$, in 2001, there was no specific content discrimination for nurses' qualification. It should be noted that the contents related to the evaluation and the indication of special coverages are separate topics for qualification courses, updating and specialization.

Nursing professionals are increasingly investing in improving their knowledge through post-graduation and qualification courses to meet the needs of the market, which is becoming more competitive ${ }^{14,15}$. Due to the nurses' main role in public health, they specialize in this area. 
The ideal cover should guarantee an adequate environment for healing, controlling moisture, allowing the control of excess exudate, allowing the gas exchange, providing thermal insulation, controlling the proliferation of bacteria, preventing contact with contaminating particles and toxic of the wound and guaranteeing the possibility of removal without trauma ${ }^{16,17}$. The choice of the type of cover is directly related to its function that can be: protection and absorption of moisture; absorption of exudate and odors; debridement; cleaning and prevention of exogenous contamination; compression to minimize fluid accumulation; and immobilization or protection against mechanical injury. The therapeutic decision should be dynamic, adapting continuously to the clinical evolution of the wound ${ }^{18,19}$.

Nurses' knowledge is a mandatory and necessary part of their activities, in which the theoreticalpractical knowledge must be related, demonstrating their abilities and competences to practice the profession. The perception for the treatment of wounds covers technologies, indications, costs and effectiveness, streamlining the treatment ${ }^{16}$. Faced with this, it is necessary that the professional has adequate knowledge of the products and the indication of special coverages.

The correct indication of the coverages is part of the treatment of wounds among some steps that must be followed: to evaluate and reassess the patients according to necessity, as it may be necessary to change the type of coverage; establish goals for healing; organization of the team that involves the nurse and the caregivers/family to follow the care and management of the wounds; establish and implement a plan, evaluating the greater necessity of the wound in its stage so that effective cicatrization begins, that is, to indicate the correct coverage for each stage of the wound; documentation, including the conduct and evolution of the wound through periodic evaluation ${ }^{20}$.

Special covers are semi-occlusive devices designed to temporarily act as skin substitutes, promoting optimum conditions of cicatrization through maintenance of ideal moist environment ${ }^{17}$.

Regarding aspects related to nurses' knowledge about the indication of special coverage, it was observed that nurses do not have specialization in the area, being below $50 \%$ in most of the indications of each special coverage.

In the indication of the coverage of hidrofibra with silver in another research ${ }^{14}$, the nurses also presented less knowledge. For the coverage of hydrocolloid, none of them knew how to make the indication for autolytic debridement. For the author, the result of the research was justified by the routine use of the coverage only for the prevention of pressure injuries ${ }^{16}$.

The hydrogel coverage in this study was the one that obtained the highest number of indications for their respective purposes. This data is similar to the other study16, which also showed more correct answers about the indication of this coverage, but with unsatisfactory results. The data demonstrate that part of the nurses does not have the proper knowledge for the use and prescription of the coverage. Also, it can be observed in the study that most professionals do not cite the function of autolytic debridement in the coverings that have this function, such as hydrocolloid, hydrocolloid with silver, calcium alginate, silver foam, hydrofibra and hydrogel.

Little can be found in the literature on nurses'specific knowledge regarding the indication of coverage, which, if found, demonstrates the lack of minimum knowledge to provide care. Commonly, protocols for the standardization of coverage that guide health care are found.

Care should be performed in a personalized way and according to the unique needs of each patient. Sometimes it is necessary to frame the patient in specific programs, such as smoking, diabetes and nutritional control. The correct prescription of the coverages is important, but the care set is essential for the effectiveness in the treatment ${ }^{20}$.

The PHC service has a protocol aimed at improving the quality of care and standardization of MHD conduits. It can be verified that the answers of the correct indications of each type of coverage were similar in all groups. The data point to the group with specialization/qualification, which should have a greater assertive value in relation to the group without any specific qualification.

The results can be compared in the literature, which identified that most of the nurses had foundations on the injury, but reported difficulties in identifying it and also did not know its pathophysiological mechanism ${ }^{21}$. The same characteristic is also found in another study ${ }^{6}$, in which few interviewees correctly detailed the characteristics of the wound evaluated in the care of people with malignant cutaneous injuries.

The nurse who provides care in PHC in the treatment of wounds is responsible for knowing the correct 
indication of each coverage and also the applicability according to the etiology of the wound and the stage in which it is, from the understanding of the physiology of cicatrization ${ }^{18,22}$.

The coverage options have benefits for the patients and greater safety for the professionals involved in care $^{23}$. Although nurses use a manual for wound care standardization, in this study the difficulties of using what is proposed occurs due to the lack of recommended products.

The nurse's care with the patient in the PHC requires, together with the practice of the indication of coverages and approach, to understand the physiology of the skin and the cicatrization. By associating the scientific knowledge about the types of coverage existing in the market, the lack of this knowledge makes it difficult to correctly diagnose the type of injury and also indicates the special coverage adequate for the prevention or treatment of the injury ${ }^{22,23}$.

The knowledge about the appropriate coverage to be used depends on the knowledge about composition, mechanism of action, indication, warnings, mode of use and interval of exchange of each option. Knowing how to evaluate and identify the needs of the wound complements the decision about which objective should be reached to optimize that scar process.

It was possible to observe that even nurses with qualification/improvement face difficulties to indicate the coverage due to the type of indication of each product. The data are noteworthy because the care in the PHC has a manual with standardization for wound treatments. The limitations of the study refer to the number of participants and the geographical difficulty for access to all PHC units in the municipality surveyed. After completing the survey, the results were presented to the MHD managers.

\section{CONCLUSION}

The results of the study allowed us to evaluate that even nurses receiving a qualification/improvement course on wound treatment offered by MHD, the percentage of indication of each special coverage was less than $50 \%$ in almost all the questions surveyed, which denotes knowledge insufficient on the subject.

When the comparison between the group of nurses who has qualification/improvement in wounds and what has not, there is no statistically significant difference. The coverage with the highest percentage of accuracy was the hydrogel, and the inadequate indication was the hydrocolloid.

It is possible to infer that, due to insufficient knowledge to indicate the special coverages, the performance of the specialist nurse in this area would contribute significantly to the patient, regarding the treatment of the wound and the service, regarding the waste of material.

It is hoped that this study could serve as a fulcrum for future investigations in the area, as well as for a possible revision in the reordering of $\mathrm{PHC}$ services that perform special healings.

\section{AUTHOR'S CONTRIBUTION}

Conceptualization, Caveião C and Hey AP; Methodology, Caveião C; Hey AP and Sales WB; Investigation, Tavares ELP and Souza E; Writing - First version, Caveião C; Tavares ELP and Souza E; Writing - Review \& Edition, Caveião C; Hey AP; Sales WB and Silva MMBG; Supervision, Caveião C.

\section{REFERENCES}

1. Garnelo L, Lucas ACS, Parente RCP, Rocha ESC, Gonçalves MJF. Organização do cuidado às condições crônicas por equipes de saúde da família na Amazônia. Saúde Debate. 2014;38(Espec):158-72. $\quad$ https://doi.org/10.5935/01031104.2014S012

2. Ministério da Saúde. Secretaria de Atenção à Saúde. Departamento de Atenção Básica (BR). Normas e Manuais Técnicos. Cadernos de Atenção Primária, n. 29. Brasília: MS; 2010 [cited 11 dez 2017]. Available at: http://bvsms.saude. gov.br/bvs/publicacoes/caderno atencao primaria 29 rastreamento.pdf.

3. Azevedo IC, Costa RKS, Holanda CSM, Salvetti MG, Torres GV. Conhecimento de enfermeiros da estratégia saúde da família sobre avaliação e tratamento de feridas oncológicas. Rev Bras Cancerol. 2014;60(2):119-27.

4. Cavalcante BLL, Lima UTS. Relato de experiência de uma estudante de enfermagem em um consultório especializado em tratamento de feridas J Nurs Health. 2012;1(2):91-103. 
5. Conselho Federal de Enfermagem. Resolução COFEN No 567 de 29 de janeiro de 2018 [Internet]. Brasília, DF; 2018. [cited 07 nov 2018]. Available at: http://www.cofen.gov.br/ resolucao-cofen-no-567-2018_60340.html.

6. Smaniotto PHS, Ferreira MC, Isaac C, Galli R. Systematization of dressings for clinical treatment of wounds. Rev Bras Cir Plást. 2012;27(4):623-66. https://doi.org/10.1590/S198351752012000400026.

7. National Pressure Ulcer Advisory Panel. NPUAP Pressure Injury Stages [Internet]. Washington: NPUAP; 2016 [cited 11 dez 2017]. Available at: http://www.npuap.org/resources/educational-andclinical-resources/npuap-pressure-injury-stages/.

8. Leite AP, Oliveira BGRB, Soares MF, Barrocas DLR. Uso e efetividade da papaína no processo de cicatrização de feridas: uma revisão sistemática. Rev Gaúcha Enferm. 2012;33(3):198-207. https://doi.org/10.1590/S198314472012000300026 .

9. Cunha MB, Sousa LRM, Castro JMSS, Melo GL, Sousa LRG, Carvalho ML. Avaliação do conhecimento da equipe de enfermagem de um hospital público sobre a prática de curativo. Rev Interd. 2015;8(1):83-90.

10. Conselho Nacional de Saúde. Resolução No 466 de 12 de dezembro de 2012. [Internet]. Brasília, DF; 2012. [cited 11 dez 2017]. Available at: http://conselho.saude.gov.br/ resolucoes/2012/reso466.pdf.

11. Souza LL, Araújo DB, Silva DS, Bêrredo VC. Representações de gênero na prática de enfermagem na perspectiva de estudantes. Ciência \& Cognição. 2014;19(2):218-32.

12. Silva KL, Sena RR, Tavares TS, Martins ACS. Oferta de cursos de graduação de enfermagem no estado de Minas Gerais. Texto contexto - enferm. 2011;20(Espec):124-130. https:// doi.org/10.1590/S0104-07072011000500016.

13. Conselho Nacional de Educação. Câmara de Educação Superior. Resolução CNE/CES No 3 de 7 de novembro DE 2001 [Internet]. Brasília, DF; 2001. [cited 11 dez 2017]. Available at: http://portal.mec.gov.br/cne/arquivos/pdf/ CES03.pdf.

14. Salomé GM. Avaliando lesão: práticas e conhecimento dos enfermeiros que prestam assistência ao indivíduo com ferida. Saúde Coletiva. 2009;6(35):280-287.
15. Erdmann AL, Peiter CC, Lanzoni GMM. Brazilian research groups in nursing: comparison of 2006 and 2016 profiles. Rev Gaúcha Enferm. 2017;38(2):e69051. https://doi. org/10.1590/1983-1447.2017.02.69051.

16. Prado AR, Barreto VPM, Tonini T, Silva AS, Machado WCA. O saber do enfermeiro na indicação de coberturas no cuidado ao cliente com feridas. ESTIMA, Braz J Enterostomal Ther. 2016;14(4):175-82. https://doi.org/10.5327/Z18063144201600040004.

17. Silva DRA, Bezerra SMG, Costa JP, Luz MHBA, Lopes VCA, Nogueira LT. Pressure ulcer dressings in critical patients: a cost analysis. Rev esc enferm USP. 2017;51:e03231. https:// doi.org/10.1590/s1980-220x2016014803231.

18. Melo EM, Fernandes VS. Avaliação do conhecimento do enfermeiro acerca das coberturas de última geração. ESTIMA, Braz J Enterostomal Ther. 2011;9(4).

19. Silva ACO, Rodrigues Filho ESF, Sousa GRS, Silva JFS, Silva $\mathrm{AL}$, Araujo CMS. As principais coberturas utilizadas pelo enfermeiro. Revista Uningá. 2017;53(2):117-23.

20. Canadian Association of Wound Care. Foundations of best practice for skin and wound management. Best practice recommendations for the prevention and management of wounds [Internet]. Toronto; 2016. [cited 11 dez 2017]. Available at: https://www.woundscanada.ca/docman/ public/health-care-professional/bpr-workshop/165-wc-bprprevention-and-management-of-wounds/file.

21. Anjos ET, Teixeira LA, Rodrigues MA, Paula MAB, Vasconcellos ACLP. O que os enfermeiros de saúde coletiva sabem sobre o tratamento das úlceras venosas. ESTIMA, Braz J Enterostomal Ther. 2007;5(4).

22. Teixeira AKS, Menezes LCG, Oliveira RM. Serviço de estomaterapia na perspectiva dos gerentes de enfermagem em hospital público de referência. ESTIMA, Braz J Enterostomal Ther. 2016;14(1):3-12. https://doi. org/10.5327/Z1806-3144201600010002.

23. Chayamiti EMPC, Yano TK, Mabtum A, Carmo DHP, Garcia MLB, Viliod MCL, et al. Dificuldades para o uso de inovações: assistência às pessoas com feridas crônicas nas unidades de saúde de Ribeirão Preto. ESTIMA, Braz J Enterostomal Ther. 2007;5(3). 